\title{
Seven Pillars of Business Ethics: Toward a Comprehensive Framework
}

\section{William Arthur Wines}

\begin{abstract}
This article first addresses the question of "why" we teach business ethics. Our answer to "why" provides both a response to those who oppose business ethics courses and a direction for course content. We believe a solid, comprehensive course in business ethics should address not only moral philosophy, ethical dilemmas, and corporate social responsibility - the traditional pillars of the disciple - but also additional areas necessary to make sense of the goings-on in the business world and in the news. These "new pillars," that we advocate include moral psychology, organizational design and behavior, motivational theory, and a unit on how society, business, and law interact. This last unit builds upon the work of Francis P. McHugh (1988) who urged an integration of "disciplines related to business ethics." Our seventh pillar would encompass an integration of law, socio-political theory, and policy to demonstrate how business helps construct its own regulatory framework. The concluding recommendation is for a comprehensive "Seven Pillars" of business ethics approach.
\end{abstract}

KEY WORDS: areas of coverage for business ethics, interactions of society, business, and law, Corporate social responsibility, ethical dilemmas, moral philosophy, moral psychology, moral reasoning, motivational theory, organizational dynamics, reasons to teach business ethics

\section{Introduction}

A colleague addressed me the other day, "You don't teach what $90 \%$ of us consider to be business ethics. Business ethics should teach compliance [presumably with regulatory rules]." I replied that regulation and compliance were the subjects of Legal Environment of Business. ${ }^{2}$ Business ethics is not a course in criminal justice, and mainstream practitioners understand ethical issues start, in general, where the law ends. ${ }^{3}$ Finally, I reminded him that every functional area professor has a duty to make students aware of the relevant bright lines, the established legal boundaries in her/his area.

We parted amicably and holding the same differences. His departing comment was: "You should be teaching compliance; that's what the business community expects you to be doing." Our discussion illustrates one of the central issues in business ethics, namely: what are the reasons for teaching business ethics? Why should it be taught? Some have argued that business ethics courses should be eliminated and replaced with more business law courses (Prentice, 2002). Harvard responded to the current rash of ethical and legal meltdowns (Farrell, 2006) by extending the length of business ethics modules. ${ }^{4}$ Still other business schools have started introducing their MBA students to white-collar convicts in the hopes of "scaring them straight." 5

One line of argument holds that there is no use in trying to teach ethics at the college or graduate level because it is simply "too late" if students do not know the difference between right and wrong by then (Berleson and Steinier, 1964, p. 562). A variant of that argument states that business ethics cannot be taught as long as business educators refuse to examine the ethical foundations of their basic model (Berg, 1989, pp. 111-132). A somewhat controversial position is that business ethics as taught is generally irrelevant to business managers because it teaches an otherworldly type of moral perfectionism (Stark, 1993). As can be seen, many different viewpoints proceed from many different presumptions about why we teach business ethics. These presumptions generate an even wider variety of opinions about what such a course should cover (McHugh, 1988, pp. 3-18); and these opinions 
cover a wide range of options as to what the goals of such courses are. This article will address these fundamental issues. ${ }^{6}$

Underlying the concerns of those who oppose business ethics courses seems to be an unstated premise: if we are going to allow a business ethics course in our curriculum, we need to have assurances that students who take the course will become better and more law-abiding managers (Levin, 1990; Miller and Miller, 1976; Vogel, 1987). A corollary to that premise is that proponents of business ethics need to be able to prove with hard evidence (read that "empirical data") that a single course in business ethics will have the desired effect using a model that holds all other variables constant. Of course, such a proof is unavailable; and even the most highly sophisticated computer models cannot hold every other variable constant except a single college course over the span of a 40-year business career.

Before we can seasonably address what should be taught in a business ethics course, we must respond to our colleagues who oppose offering such a course (Kelly, 2002). Consequently, the first part of this article will provide a response to the argument that business ethics courses should not be in the curriculum because such courses cannot be proven to increase students' motivations to be law-abiding managers (Academe Today, 1999; Fraedrich and Ferrell, 1992). The second part of this article proposes requiring a freestanding and an expanded course in business ethics as part of undergraduate and MBA core curricula. ${ }^{7}$

The expansion of the traditional concept areas covered in business ethics should include disciplines beyond moral philosophy and corporate social responsibility. These "new pillars" should include moral psychology (Gilligan, 1982), organizational design and behavior (Wines and Hamilton, 2004), motivational theory (Maslow, 1954) and responses to authority (Blass, 2000), and a short history of civilization (civics) (McHugh, 1988). This article proposes a "Seven Pillars" of business ethics approach - with an acknowledgment of T.E. Lawrence's contribution (Lawrence, 1926).

This article summarizes the traditional three (3) pillars of business ethics. ${ }^{8}$ A review of the subjects covered in a sample of popular business ethics textbooks confirms that generally they deal with the three traditional pillars (Hartman, 1998, p. 1).
However, some newer topics are emerging in the journals (Premeux, 2004) and at conferences. ${ }^{9}$ Just as education itself cannot be completely "values-neutral," (Sloan, 1980) the selection of topics and their emphasis in any course reflects the underlying value sets of a college, department and/or instructor. ${ }^{10}$ However interesting such a topic might be, it goes well beyond the scope of this article. Simple integrity (Dubrow and Wilkinson, 1984) requires instructors stay within the bounds of widely held moral values.

\section{A response to "why teach business ethics?"}

The clash of cultures in the business schools

In a prophetic 1987 article, Mulligan described the clash of two cultures in colleges of business. $\mathrm{Pu}-$ shed by the Pierson et al. (1959) and the Gordon and Howell (1959) reports, business schools have increasingly embraced the mathematic, scientific, empirical model. The gain of scientific and empirical rigor has come at the expense of qualitative analysis and of the humanities. In the transition, the two cultures of learning have moved into opposing and nearly mutually exclusive postures. Mulligan wrote:

... The deepest differences between the two cultures are philosophical differences, which propel the cultures in opposite directions - into contrary and, nearer the extremes, mutually exclusive views concerning what counts as a method for increasing knowledge and what counts as an investigable object of study. (1987, p. 595).

As Mulligan points out later in this profound work, the collision point between the two cultures comes at the juncture of business ethics and the traditional behavioral sciences.

At bedrock, those who profess ethics believe that human beings are autonomous moral actors capable of making meaningful choices. ${ }^{11}$ This is where the great "disconnect," so to speak, occurs between the business ethicists and their colleagues, the empiricists. As Mulligan points out, "David Hume's watershed observation, made in 1737, that you cannot get a moral 'ought' from an empirical 'is' still stands.” (1987, p. 596) Consequently, Karl Popper 
and numerous other scientists, who saw moral judgments lacking falsifiability, believed moral judgments were outside the rules for scientific discovery. The behavioral scientists, in general, see human beings as mechanisms to be studied. This is the "root of ... what C.P. Snow called the 'incomprehension and dislike' between the two cultures in business education." From the perspective of a behavioral scientist such as B.F. Skinner, an act of free will is gibberish - an event without a cause or, worse, an event that causes itself.

Now, almost two decades after Mulligan penned his article, the triumph of the scientific, mathematical, empirical school is almost complete. Business ethics courses are disappearing from the curricula of M.B.A. programs; and the rate of extinction seems to be increasing (Kelly, 2002). Eighteen years ago, only $7 \%$ of the M.B.A. programs had required freestanding courses in business ethics (Paine, 1988, p. 10); now that number appears to be on the decline along with business ethics modules and electives in business ethics.

Diane Swanson of Kansas State University and William Frederick, emeritus from the University of Pittsburgh, combined in the fall of 2002 to push for a national Task Force on Business Ethics Education (Kelly, 2002, p. 4). What they were seeking was "nothing less than a "comprehensive inquiry into the role that business schools and their accrediting agency, AACSB, play in inculcating in their students a normatively amoral attitude that permits, tolerates, and at times encourages unethical, fraudulent, corrupt and illegal behavior by business practitioners." Swanson and Frederick attempted to mobilize faculty to protest that the new draft AACSB standards did not go far enough in encouraging courses in business ethics. In fact, the draft standards circulating in the fall of 2002 did not call for a specific course in ethics at all. Rather, the current standards, adopted on April 25, 2003, continued the AACSB policy of flexibility from 1990 and merely listed "Ethical understanding and reasoning abilities" as one of the several so-called "learning experiences" that should be included somewhere, anywhere in the undergraduate curricula (AACSB, 2003). In the author's experience, when everyone on the $\mathrm{COB}$ faculty is responsible for teaching ethics, business ethics does not get taught. ${ }^{12}$
As sincere as its proponents are, the Task Force's line of argument ultimately misfires. It may also play in the hands of the Task Force's antagonists. One response to such an argument might well be to challenge the Task Force "to prove that a required course in business ethics in a two-year M.B.A. program generates a more law-abiding, a more ethical business manager." Such a burden of proof cannot be carried. Certainly, it is one thing to charge that the "orthodox single-set value system" of the business faculty (Conry and Nelson, 1989, p. 4) generally aids and abets misconduct by corporate managers; but it is an entirely different matter to take up the burden of proof. "Proof" invokes the scientific, empirical model; and unhappily moves the debate back into the court of the empiricists.

\section{The argument from purposes of higher education}

Moreover, such a line of argument is fundamentally flawed because no single course in higher education is designed to be or supposed to be "life-changing" or a "redemptive" experience ${ }^{13}$. Any attempt to prove otherwise is destined from the beginning to fail. The line of argument that may have the best chance for success is one that finds its roots in the purposes of state-supported public higher education in the United States (Wines, 2004, pp. 13-14). In the next few paragraphs, the nature of that argument will be roughed out.

First, the history of a "liberal education" is one of a "broad," rather than liberal in the political sense, education (Cronin, 2004). Education was, and is, designed to (a) equip students to take charge of their intellects (life-long learners) (Bloom, 1987); and (b) prepare the student to take a meaningful role in participatory government as an active and informed citizen. ${ }^{14}$ The role of vocational training in the 19th century was performed mostly through apprenticeships with the exception of preparation for religious ministry. ${ }^{15}$

By the beginning of the 20th century, some types of vocational training had found their way inside the ivy-covered walls of the emerging universities. ${ }^{16}$ Agricultural science and animal husbandry were part of the land-grant package deal. ${ }^{17}$ Law started to become a course of study when Harvard University 
opened an early American law school in 1817. Commerce schools came of age in the 1920's ${ }^{18}$ when "the business of America was business." 19 Previously, agriculture had been learned working on the family farm; future lawyers had worked as "clerks" and "read for the bar;" and young men had gotten their start in business as messenger boys, clerks, or helping out in the family trade. Sometime around the year 1900, the "universities" decided to help bring the new secular religion of "scientific progress" to those seeking to start out in farming, law, business, and other trades - such as medicine, veterinary science, and dentistry, to name a few.

The objective of balance and providing both a liberal arts foundation and professional skills to the emerging business manager has been lost. Even the pretense of balance, which the AACSB embraced as late as the 1990 curricula standards, seems to have disappeared. Vocationalism, often disguised under the righteous cloak of "academic rigor," has not only taken the high ground but now seeks to expel all non-adherents. The term "rigor" is sometimes used as a code word for the mathematical, scientific and empirical tradition - as in, "any course without multi-regression analysis lacks serious academic rigor." In less than 50 years, the desire of commerce schools to maintain their status on campus by pursuing the "new" rigor of the behavioralists has generated an almost complete monopoly among the empiricists; and the humanities, for centuries an integral part of a traditional liberal education, have been almost completely driven from the parts of the Academe where commerce rules (Hosmer, 1999; Mulligan, 1987; Wines, 2004).

For several reasons, eliminating the last remnant of the humanities from Colleges of Business will ill serve American society. First, business leaders in our society are frequently tasked with leading important community functions, every thing from school boards to United Funds to city councils (Wines, 2004, p. 16). We are turning out new managers who are oblivious of the nature of the problems confronting the society and clueless as to the history, culture, and learning encompassed by them. Second, business students come to the university with the lowest level of moral reasoning skills of any graduate students (Conry and Nelson, 1989, pp. 20-22) and are the only students to experience decline in their reasoning skills as they finish their studies (1989, p. 20).
As a nation, we should take this information seriously (Waddock, 2004). Adding a single required course in business ethics obviously will not cure such a serious problem. However, re-establishing the balance in higher education by re-emphasizing the reasons why we have state-supported public education may well help reduce this problem. Business graduates, many of whom struggle to recognize the nature either of a moral issue or of moral reasoning, have little probability of reaching a morally defensible solution. ${ }^{20}$ Business graduates who have some grounding in the humanities and in the history of Western civilization have a much better chance of reaching a defensible solution. Incorporating a required course in business ethics in all AACSB programs would be just barely a start in the right direction; but it could be an important first step.

\section{The telling nature of the challenge itself}

On another level, the challenge to demonstrate that business ethics courses turn out more sensitive and better-informed managers is, itself, a reflection of the biases that currently govern American business and commerce (Mitchell and Scott, 1990). Business schools, without trying, turn out confirmed Utilitarians (Mitchell and Scott, 1986). This challenge is an output-based "show us that your course produces" type of confrontation. It is purely classical utilitarian in outlook (Rachels, 2003, pp. 91-103). Such a question exemplifies the white-male consciousness approach so well defined and described by Ann Wilson Schaef (1981, pp. 108-114). It reflects the reality that business is a white-male dominated practice $^{21}$ that requires women, people of color, and others to fit its mold if they want to succeed. It values neither process nor diversity. Why have more women not become CEO's in the past two decades or why are women business professors so rare in AACSB faculties? ${ }^{22}$ Some of the answers to those questions are also mirrored in the challenges confronting anyone advocating a business ethics course.

On a less Olympian level, the main fault of classical utilitarianism is that it has an inadequate concept of justice (Rachels, 2003, p. 106). Thus, it seems business ethics courses are subject to challenges that other courses do not face. A level playing field would require, for example, that management 
faculty prove their students will be better life-long managers than they would have been without a management course; similarly, before we approve an English composition course, show us that students of English will be better written communicators than they would have without such a course. Such improbable challenges seem to be reserved exclusively for business ethics courses and spring from a zealous animosity that seems based, in part, on a peculiar xenophobia.

Perhaps, this reflects the classic work that showed business graduate education starts with students who are the least advanced in moral reasoning skills and then produces stunted versions for its graduates (Conry and Nelson, 1989, pp. 20-22). The questions of education, quality of life, ability to think about difficult value choices, and fair play seemingly do not figure prominently in the thinking of the scholar-warriors who defend the temple of commerce from those of us who would inculcate business students with moral curiosity (Hosmer, 1999; Mulligan, 1987; Wines, 2004).

\section{Basic constructs in business ethics}

\section{Moral or ethical: some vocabulary}

Even though the terms "moral" and "ethical" are used interchangeably in everyday conversation, we observed that some distinctions in their usage in this paper that we believe to be helpful (Wines, 2006, p. 47). The term "morals" will denote the collection of moral principles - the prima facie (i.e., rebutable rather than absolute) rules that everyone has that operationalize our values. An individual's moral code is, thus, a set of moral principles that guides his or her actions; we all have such a code even though some of us might have difficulty articulating it. Others may articulate one set and live by another. For our purposes, an individual's genuine moral code is the one that drives his or her life choices. Ethics refers to a higher, more abstract activity than the direct application of personal morals to behavior choices.

Ethics, for our purposes, is the cognitive, analytical, systematic and reflective application of moral principles to complex, conflicting or unclear situations. Business ethics, then, should not be a course about white-collar crime. Socrates said that when addressing questions of morality, "We are discussing no small matter, but how we ought to live."(Rachels, 2003, p. 1) A solid, comprehensive course in business ethics should address not only moral philosophy, ethical dilemmas, and corporate social responsibility - the traditional pillars of the discipline $^{23}$ - but also several other areas necessary to make sense of the goings-on in the business world.

James Rest of the University of Minnesota had identified four steps in moral decision-making: (a) moral sensitivity, (b) moral judgment, (c) moral will, and (d) moral action (Rest et al., 1986). Over the years, the first step, moral sensitivity, has presented much difficulty for many people in business. There is a popular misconception that somehow what people do at work and the health of their moral consciousness are not related (Wines, 1999, pp. 3-4). Some people presume that decisions in the realm of economics are value-free; and that "since the laws of the market" dictate behavior, the decision-makers cannot be held morally responsible. This is an indefensible position (Hosmer, 1987, pp. 33-54); it promotes abuse of economic power; and it leads indirectly to more federal and state regulation of business. Such a position is the "institutionalization of non-responsibility." (E.F. Schumacher as quoted in Solomon and Hanson, 1983, p. 209.)

\section{Levels of business ethics}

Much attention is paid in both the classroom and in the literature to the issues of moral decision-making faced by the individual (Shaw and Barry, 1998). This is certainly an important level of decision-making, but it is only one of three levels that a course in business ethics should address: (1) the individual; (2) the organizational level; and (3) the societal/community level of decision-making (Solomon and Hanson, 1985, p. 55).

Organizational structure and dynamics frequently create a corporate culture that pressures individuals to suspend their traditional notions of moral responsibility. Surveys of business managers indicate that they feel compelled by organizational dynamics and peer pressure at work to compromise their values; $70 \%$ of a sample of 6000 managers and 
executives felt pressure to conform and compromise personal values (Wartzman, 1987). Rick Wartzman asserts, after reviewing 10 academic studies on corporate culture and codes of conduct, "... even the most upright people are apt to become dishonest and unmindful of their civic responsibilities when placed in a typical corporate environment."'(Wartzman, 1987, p. 27) Anyone seeking to build better organizations should review the classic studies on authority and on the power of role expectations such as those of Stanley Milgram $(1965,1967)$ at Yale University and Philip Zimbardo's famous Stanford University prison experiment (Haney et al., 1973).

A third and final level of social analysis is required if we decide that our corporate culture should be responsive to social needs and concerns (Bowie and Duska, 1990, pp. 111-117). In order to have a yardstick that helps us decide when to reject society's demands, we must have some concept of what a just and compassionate society (Rawls, 1971, p. 3) would look like. Any analysis of this concept would take us beyond the scope of this article; but this level of ethical analysis is important and is mentioned here to provide a complete perspective on what I am proposing.

Mental gridlock: the stimulus for growth

Elenchus is the Greek word for mental gridlock that Socrates produced in those who dialogued with him. ${ }^{24}$ Modern moral psychology has discovered that, indeed, Socrates was right about distress or irritation stimulating moral growth; now, however, thanks to Lawrence Kohlberg and James Rest, we can measure it. In business ethics classes, students are encouraged by situational dilemmas to examine some of their unexamined or automatic stances. ${ }^{25}$ Some of these stances have become so reflexive (non-cognitive) that they are generated by moral principles that have become ideological or attitudinal or habitual (Wines and Napier, 1992, pp. 832-834). Using hypothetical problems that are deliberately drafted with built-in ambiguities encourages students to dredge up their "buried" values and reflexive assumptions about people and examine them in the sunlight of cognition and class discussion.

\section{Traditional pillars of business ethics}

\author{
Moral philosophy as the basic unit
}

Since business ethics is almost universally understood as a course in applied ethics, that is, moral philosophy in the context of a life lived in business and commerce, the first unit in a course on business ethics will almost always be a summary of schools of normative ethics. In the 1970's, it was not uncommon for the schools of ethics to be divided simply into consequential (such as utilitarianism) and nonconsequential (such as Kantian ethics) (Barry, 1979). Some still covered Aristotle's ethics of being; but, in general, Aristotle had yet to recover from a decline induced in large part by Bertrand Russell ${ }^{26}$ and others who at the start of the 20th century had been dismissive of Aristotle's contribution.

Thirty years later, Aristotle has been rehabilitated and his ethics of being are now included in many business ethics textbooks (Halbert and Ingulli, 2000, p. 29). This also, conveniently, opens the way for inclusion of feminist ethics or the ethics of care based upon the work of Carol Gilligan in Developmental Psychology (Gilligan, 1982; Noddings, 1984). Some distinguished scholars argue that the Ethics of Care is really a subset of Aristotle's virtue ethics, or, perhaps more defensibly, merely another example of ontological ethics (Rachels, 2003, pp. 160-172).

\section{Corporate social responsibility}

Although Nobel Laureate Milton Friedman and certain other economists and conservative commentators believe the market will solve virtually all problems and that business has no need of a social conscience (Friedman, 1970), main stream business ethics has included Corporate Social Responsibility [hereinafter CSR] as a mandatory area of study since the late 1960's (Rue and Byars, 1986, pp. 61-62). One of the reasons for this is that CSR is seen by many as an important alternative to more regulation of business by the state and federal governments. Most observers, liberal moderate - or conservative, know that regulation is inherently inefficient (Stone, 1975) and acts as an obstruction to American businesses competing as 
effectively as possible in the rapidly growing global economy.

\section{The use of experiential ethical dilemmas}

For over two decades, many business ethics instructors have been teaching the basics of moral philosophy and then using ethical dilemma situations to encourage business students to examine some of their automatic stances in areas of business management. ${ }^{27}$ This can be done in an upper-division ethics course in which the students are first thoroughly acquainted with major schools of moral philosophy. Because of the increasingly global nature of commerce, this effort is frequently done from the perspective of cross-cultural ethics, although not always in multi-national situations (Greider, 1997). Crosscultural ethics can be encountered without leaving town almost everywhere in the U.S.A. Studies have shown that interventions using ethical dilemmas can stimulate moral reasoning levels in business students (Conry and Nelson, 1989).

\section{The new pillars of business ethics}

Moral psychology and Kohlberg's scale

Moral psychology is a relatively new discipline, and, for most business faculty, an unfamiliar discipline. Jean Piaget laid a foundation upon which Lawrence Kohlberg erected the main structure: a theory of moral development that has three levels and six stages (1984). Kohlberg developed an 8-hour interview that could be used to determine a subject's principal stage. James Rest refined this testing to a standardized 2hour pencil and paper test that allowed large scale testing and facilitated greater research (1986). Using experimental groups and control groups, research in college classes has demonstrated that intervention techniques can successfully stimulate an increased rate of moral reasoning development.

U.S. business generally seems to be making little progress toward eliminating the causes of legal and ethical "meltdowns." Look at recent disasters such as Arthur Anderson, Enron, Tyco, Global Crossing, and World Com (Wines and Hamilton, 2004, pp. 50-52). Some of these legal and ethical "meltdowns" are reminiscent of earlier incidents such as Equity Funding in the 1970's. ${ }^{28}$ They do not readily lend themselves to simplistic or reductive approaches such as "just follow the golden rule and your business will never have problems." In Equity Funding, for example, over one hundred people knew that the company was fraudulently creating insurance policies to sell to re-insurers and, yet, no one said anything until a discharged employee blew the whistle. All of these people could not have been "bad" or "evil" people. How can it be explained?

Corporate culture and the impact of organizational design

The classic case of a rigid, hierarchal organization that has generated disasters is the case of NASA, the National Aeronautical \& Space Administration. ${ }^{29}$ Even after Challenger, the corporate culture at NASA remained rigid and discouraged communication across administration levels (Langewiesche, 2003). One of the results was the loss of the Space Shuttle Columbia in February 2003. There are studies suggesting strongly that rigid, hierarchal organizations are more prone to legal and ethical meltdowns than are less-rigid, flatter organizational structures with more open communications patterns (Wines and Hamilton, 2004). In short, good people will do bad things if they are placed in an environment where doing anything else threatens their livelihood and ability to support their dependents.

This is not to denigrate the concepts of manager as moral decision-maker or the corporation as a social moral agent. It is, however, an argument that such a limited approach is inadequate given the level of knowledge about how to design a more responsive, more moral organization.

Studies in obedience to authority \& motivation at work

Stanley Milgram did groundbreaking studies at Yale in the early 1960's (1963, 1965). But Phillip Zimbardo at Stanford took Milgram's work to new levels with his Stanford Prison Experiment in the 1970's (Zimbardo et al., 2000, pp. 193-194). Over 20 years ago, we watched an NEA local struggle with an anti-teacher Board of Education in a small town in the upper Midwest. The 
union's lawyer and the NEA local organizer decided to run "one of their own" for the board in a non-bargaining election year. They backed a college professor who was married to one of the union activists. Their hope was that by getting an educator on the otherwise hostile board they could, at a minimum, get someone who understood and was sympathetic to their position inside the school board. This, they hoped, would improve their chances for negotiating a favorable agreement without a strike.

This tactic backfired on them. The professor soon was acting and talking like any other elected board member and trying to impress the other board members with his concern for the taxpayers' dollars. In a year, the professor was elected President of the Board. That year, the town experienced its first teachers' strike in history. The household of the college professor was torn; a line went down the middle of the kitchen separating management and labor. The town was divided. Social scars still linger in the teachers' lounges two decades later. What happened? The college professor had become "one of them." He was no longer playing the role; the role was playing him. ${ }^{30}$

The power of such a situation was vividly demonstrated in Zimbardo's famous Stanford Prison experiment. In 1972, Professor Zimbardo and two Graduate Assistants, Banks and Haney, conducted an experiment in the Psychology Building at Stanford University. A group of 24, paid college volunteers, all white males, was selected for an experiment. They were screened for mental health and stability. Then, prisoner and guard roles were determined by a flip of a coin. The experiment was to last 2 weeks; but it had to be called off after 6 days because the situation had become too real.

Guards had become sadistic and aggressive and, at least in one case, were abusing the prisoners. The prisoners had started to act like "first-timers" in real prisons and experienced "a loss of personal identity" and displayed signs of "passivity, dependency, depression, and helplessness." In less than 36-hours, one of the prisoners showed signs of severe psychosomatic disturbance and had to be released early. Four other prisoners who developed signs of severe psychological symptoms were also released. The guards enjoyed the exercise of power and volunteered for extra duty without additional pay. When the experiment was terminated early, the guards were disappointed, while the remaining prisoners were elated (Brady and Logsdon, 1988).

In 1972, Professor Zimbardo explained his observations and why the experiment had to be terminated in these words:

At the end of only six days we had to close down our mock prison because what we saw was frightening. It was no longer apparent to most of the subjects (or to us) where reality ended and their roles began. The majority had indeed become prisoners or guards, no longer able to clearly differentiate between role-playing and self. There were dramatic changes in virtually every aspect of their behavior, thinking and feeling. In less than a week the experience of imprisonment undid (temporarily) a lifetime of learning, human values were suspended, self-concepts were challenged and the ugliest, most base, pathological side of human nature surfaced (Zimbardo, 1972, p. 5).

If we can induce such major behavior changes in volunteers who were paid minimum wage and playing at prison, imagine what is possible in a real situation where a person's livelihood and the economic welfare of his or her family is at stake. Such situational imperatives drive scenarios such as Equity Funding, Ford Motor Company's Pinto gas tank design (Shaw and Barry, 1998, pp. 78-80), Arthur Anderson's shredding of Enron documents (Newsday, 2002), Rely Tampon (Sturdivant and VernonWortzel, 1990), the Challenger disaster (Shaw, 1999, p. 34), and numerous others (Jennings, 1996). Good people will do bad things if we make their cubicle (box) too much like Stanford's Prison. The alternative is an open environment that promotes independent thinking and tolerates questioning and dissent. In short, we need to design organizations more like town meetings and less like the hierarchical organizational charts derived from military models.

One good question to ask business students is "how do we make organizations not like prisons?" Two writers suggested as early as 1988 that social psychology and organizational behavior were neglected areas that should be covered in business ethics courses: 
The absence of reference of the Zimbardo experiment in teaching materials is hardly surprising because it is not generally cited in articles in major journals that publish in the business ethics field. Indeed, business ethics scholars have neglected research in social psychology and organizational behavior even when it relates significantly to individual decision-making. This may be partly explained by the traditional dominance of philosophers and other academicians with little management training and little exposure to experimental methodology for business ethics research (Brady and Logsdon, 1988, p. 708).

Motivational studies make clear that Adam Smith's rational utility maximizer is not a typical 21st century employee in the United States. Pay is not a highly rated motivator, even among blue-collar employees (Rue and Byars, 1986, pp. 355-365). As Herzberg theorizes, pay is a hygiene factor, not a motivator (Herzberg, 1959, as cited in Rue and Byars, 1986, p. 361). This finding contradicts neoclassical economic theory - to the extent that employees are seen as perfectly rational economic actors. One college administrator, an ideologue of neo-classical economic theory, could not understand why offering a "bonus" of $\$ 500.00$ for each refereed publication not only failed to inspire his faculty members but also was taken as an insult. Motivation theory might have made that clear.

How society, business, and law interact

Courses that touch current events as regularly as Business Ethics does cannot help but be enriched by the addition of illustrations from current topics. There are so many to choose from that an instructor should be able to enrich the syllabus with an intellectually stimulating potpourri of current illustrations and dilemmas. Candidates for coverage might include, among others: privacy in the workplace; civil rights and affirmative action; CEO pay issues; prescription drug pricing policies; environmental issues; use of the market mechanism to distribute health care; corporate monopolies in the news media; sending jobs "offshore"; and governmental policies on plant closings.

However, the seventh pillar is not current events but rather a pragmatic mix of the subjects that will help the earnest student understand the progress of modern humanity in living together and forging cultures that attempt to promote progressive and enlightened standards of living. In a sense, this pillar builds on McHugh's work in which he listed sociology, political theory, psychology, history, economics, management studies, policy studies, and law as disciplines "related to business ethics." The seventh pillar encompasses an integration of law, sociopolitical theory, and pubic policy in a way that illuminates the evolution of modern humanity, economics, and societies. In most western countries and especially in the U.S.A., business has an important say in the design of its regulatory environment. This pragmatic reduction is necessary to make coverage of the course feasible in one semester/quarter. Going beyond what McHugh proposed in 1988, this proposal establishes new emphases and essential focuses necessary to provide the serious student with an insight into legal and ethical meltdowns in business since 1988 .

This aspect of the business ethics course should examine law not only as the basis for structuring society but also examine the ways in which businesses and large business organizations, such as the National Association of Manufacturers and the U.S. Chamber of Commerce, influence laws and legal regulations (Crane and Matten, 2004). At the third level of business ethics, it is significant for business entities to appreciate the evolution of societal norms and the changing expectations of society for business.

One example that should help support this new pillar is the case of Enron and how it helped mold utility regulations that directly and indirectly benefited it while operating under the political cover of a seeming popular mandate for de-regulation (Kaiser, in Kubasek et al., 2003, pp. E1-E8).

\section{Conclusion}

The journalist Walter Lippmann said, "What enables men to know more than their ancestors is that they start with a knowledge of what their ancestors have already learned. ... A society can be progressive only if it conserves its traditions." 31 In one sense, we face a dilemma similar to that faced by American educators in the early years of the Industrial Revolution. Like them, we need to find a way to help "shape the wider society and to provide common national goals and values." (Sloan, 1980) 
Business students are frequently indoctrinated into a utilitarian (outcome-based) ethics approach as well as into a generalized default position of "the market will take care of it" (Weidenbaum, 1990, p. 21). Consequently, they are not well prepared to deal with complex moral choices. I recommend that business ethics classes be expanded in scope of coverage to increase student awareness of the full complexities of right living in business. Edward Conry's 1989 work indicating that interventions using moral dilemmas really do stimulate moral development has become a classic (Piper et al., 1993). We now know that conditioning in the safety of the classroom will help students make better decisions "under fire" on the job. Also, substantial effort may be necessary to counter balance the market-based perspectives that are so highly commended in other business school courses.

The business ethics course at Miami University was a capstone course for seniors in which the focus was "on the manager as an ethical decision-maker and on the corporation as a social agent." (Miami Bulletin, 2002, p. 236) A capstone course is intended to be completed near the end of the undergraduate experience and "integrates liberal learning with specialized knowledge." A capstone course should emphasize "sharing of ideas, synthesis, and critical, informed reflection as significant precursors to action..." This is a good model of the multi-disciplinary and comprehensive type course that I am suggesting for wider adoption.

At a minimum, business ethics courses should be designed to help produce college graduates who do not commit the intellectual error of one-dimensional thinking $^{32}$ and who can appreciate the important and powerful role that business plays in American society and on this planet:

The economy is the dominant institution in modern society" and "the large corporation ... has become the definitive institution of modern Western culture. The large corporation dominates the modern world in much the same way that the church and the university dominated the medieval world. (Parks, in Piper et al., 1993, p. 16)

One 19th century tradition was to have the president of the college teach the senior capstone course in ethics. ${ }^{33}$ I propose that resurrecting such a practice, even if the college president does not teach the course, would be progressive, in the best sense of that word, and, perhaps, a curriculum shift that our society should support.

\section{Acknowledgements}

Professor Wines gratefully acknowledges the research assistance of Samir Bhatia, M.B.A., Miami University '04, and Andres Ocariz, M.B.A., Miami University '04 as well as the outstanding assistance of Ms. Sandra Ward-Angell, M. Div.; Ms. Susan Hurst, reference librarian, King Library, Oxford Campus; and Ms. Paula M. Hensley, senior administrative assistant, Miami University, Oxford, Ohio. He also thanks two anonymous reviewers for their helpful criticisms; Elizabeth Boyer, Missouri Western '07, for her clerical assistance; and the Business Department of Missouri Western State University for its encouragement and financial support of this project. The views expressed herein are solely those of the author; and nothing in this article should be construed as representing the views of any university with which the author is affiliated or has been previously associated, the Regents or Board of Governors of any such university, or the States in which such institutions are located.

\section{Notes}

1 Personal recollection of a conversation with Mark Cross, Ph.D., Ohio Casualty Professor of Insurance, The Richard T. Farmer School of Business Administration, in Upham Hall, Oxford, Ohio on or about March 29, 2004.

2 The Miami Bulletin: General Bulletin of Program Requirements and Course Descriptions 2002-2004 (Miami University, Oxford, Ohio) April 2002 at p. 236 provides the course description for FIN (MPT) 342 Legal Environment of Business and includes, among other subjects, the following topics: "litigation, criminal law, administrative law, and government regulation of business."

3 Id. also provides a description of the business ethics course, MPT 465 Ethics, Law, and Business as a 3 -credit course that "focuses on the business manager as an ethical decision-maker and on the corporation as a social moral agent." This description is not atypical. See also Wines, W. A., 1999, Readings in Business Ethics and Social Responsibility, (Dubuque, IA) pp. 6-9; and Crane, A. and D. Matten: 2004, Questioning the Domain 
of the Business Ethics Curriculum: Where the Law Ends or Where it Starts? (Research Paper Series ICCSR No 212004, Nottingham) www.nottingham.ac.uk/business/ ICCSR [accessed on 9 July 2004].

4 Roberto Rivera y Carlo, Business Ethics 101 June 27, 2004), Boundless Webzine at http://www.boundless.org/2002_2003/features/a0000672.html (explained that Harvard Business School "embarrassed by the role played by some of the school's alumni in the scandals had ordered a review of the school's ethics curriculum and had extended the ethics model from 3 weeks to an entire semester).

5 Roberto Rivera y Carlo, supra note 4, also discussed the program that new dean Tom Campbell has planned for the Haas School of Business at the University of California at Berkeley. The program will include field trips for students to interact with convicted whitecollar criminals. One advocate of the program describes it as "Scared Straight for Business Students." Id.

6 See Trevino, L.K. and G. R. Weaver: 1994, 'Business ETHICS or BUSINESS Ethics: One Field or Two,' Business Ethics Quarterly 4(2): 113-128 for a detailed discussion of how the choice of a normative or empirical approach to business ethics influences at a minimum five areas: (1) academic department homes; (2) language; (3) underlying assumptions; (4) theory, purpose and scope; and (5) evaluative criteria.

In 1988, one survey of directors and top executives of major corporations, Deans of business schools, and members of the U.S. Congress found that $97 \%$ of the respondents $(n=1082)$ believed American business is ethical. Touche' Ross International: 1988, Ethics in American Business (January) 2. The same survey found that these people believed that adoption of codes of ethics was "the most effective" way of encouraging ethical business behavior; and that the least effective approach was legislation. Id. Finally, the respondents said that the three (3) most helpful groups for improving American business ethics were (in rank order): (a) business people themselves; business associations; and the courts. Id. In keeping with that standard of popular faith, a contemporaneous survey of 208 AACSB Deans to which $47 \%$ responded $(n=98)$ found that only $7 \%$ of MBA programs had a separate required course in business ethics and that only $21 \%$ of the undergraduate programs had a separate required course in business ethics. Ethics Resource Center, Inc.: 1988, Ethics Education in American Business Schools (February, prepared by Lynn Sharp Paine) 10. However, the featured finding of the report was that "Ninety percent of the business schools responding to a recent Ethics Resource Center survey indicate that ethics is included in their curricula." Id. at 1 ("Summary of Findings"). A critical reading of that report raises the question of "What does the term "ethics' mean in this context, if anything?" An answer is not long is coming. The report stated that at the undergraduate level, "honesty, conflicts of interest, and marketing and advertising issues" are the topics most often covered. Id. at 4. At the MBA level, the report stated, "Conflicts of interest and product liability and safety are the topics most frequently covered." Id. Clearly, on a close reading, anything having to do with or in the general area of "Keep your nose clean, be good, and don't break the laws" qualified as so-called "business ethics coverage." Under such a scheme, "honesty" - a single value - was on a par with unfair or deceptive trade practices and OSHA violations. With such a large tent, it is amazing that the survey did not find $100 \%$ coverage.

8 The results of an unpublished April 2004 survey of the tenure-track and tenured faculty at The Richard T. Farmer School of Business Administration support the finding that faculty believed the most appropriate topics for a business ethics course were the three traditional pillars, i.e., moral philosophy, ethical dilemmas, and corporate social responsibility. Wines, W.A.: 2004, Unpublished Results of Faculty Survey on Appropriate Subjects for Undergraduate Courses in Business Ethics (July). The survey was approved by Miami University's Institutional Review Board for Human Subjects Research on April 13, 2004. $n=32$ of 113 surveys distributed by campus mail; the response rate was $28.3 \%$. A return rate of over $20 \%$ on a mailed survey with no follow-up is considered good by most authorities. See, e.g., Alreck P.L. and R. B. Settle: 1985, The Survey Research Handbook, 45-46.

9 For example, at the February 26-28, 2004 annual meeting of the Association for Practical and Professional Ethics, there were topics covering a wide range of subjects from affirmative action in admissions to organizational design, from feminism to the changing of corporate cultures. See APPE: 2004, "Program for 13th Annual Meeting," (February 11).

10 For instance, in a business ethics course, a failure to discuss hunger and poverty and the issues they raise in distributive justice might reflect an instructor's persuasion that a free market with free trade is a comprehensive solution to the world's ills. For an illustration, see Charles Krauthammer: 2004, 'So much for Democrats aiding poor,' Cincinnati Enquirer (April 9), B8.

11 Mulligan (1987, p. 597) declared that "The humanities-based ethicist, in the tradition of Plato, Augustine, or Kant, is more likely to assume that human beings (individually and in organizations) are the responsible authors of their own behavior (i.e., they are autonomous beings who set goals and act freely). 
12 Several years ago at a faculty meeting at a School of Business in the far West, a proposal for ethics across the curriculum was defeated by six votes. Among those voting against it was a Finance Professor who proclaimed that he taught all the ethics that his students needed to know. After the meeting, I politely asked him what part of ethics he taught. He responded, "I teach 'em insider trading, that's all they need to know about ethics." At the same School, a few years later, ethics was supposed to be covered by all instructors (including adjunct professors) in the Legal Environment of Business course. As Department Chair, it was part of my job to assure continuity across sections. I found that almost all the instructors were either skipping the business ethics chapter or advising their students "to go ahead and read the ethics stuff but it won't be on the test." The result, of course, was that for AACSB purposes, our self-study declared content coverage in each functional area; however, that coverage was - at best questionable and - at worst - non-existent. But see Boylan, M. and J. A. Donahue: 2003, Ethics Across The Curriculum: A Practice-Based Approach for an opposing viewpoint.

13 "Redemption," "life-changing," and "conversion" are terms most closely associated with religious experiences. For instance, "conversion" is defined as "an experience associated with a definite and decisive adoption of religion." Merriam-Webster, Inc.: 1993, Merriam Webster's Collegiate Dictionary, 10th ed., 253. At a serious level, business ethics is about opening minds to other approaches that present alternatives to the Market as God. See Cox H.: 1999, 'The Market as God; Living in the New Dispensation,' The Atlantic Monthly (March), 18-23.

14 See, e.g., Adler, M. J.: (1987), We Hold These Truths: Understanding the Ideas and Ideals of the Constitution (Macmillan, New York). See also the following famous quotation from James Madison, 4th President of the United States: "Knowledge will forever govern ignorance; and a people who mean to be their own governors must arm themselves with the power which knowledge gives." James Madison (1751-1809). [accessed on 28 April 2004] (http://madison.thefreelibrary.com).

15 Harvard College was started in 1636 by the General Court of Massachusetts for the primary purpose of training Puritans for the ministry. Today in History: September 14, Harvard. [accessed on 28 April 2004] (http:// memory.loc.gov/ammem/today/sep14.html).

16 The leader was Harvard University under President Charles W. Eliot. From 1869 to 1909, Harvard "revitalized its law and medical schools and established schools of business, dental medicine, and arts and sciences, and transformed itself into a major modern university." Today in History: September 14, Harvard, supra note 15.

17 The Morrill Act of 1862 began a process that eventually, with the addition of the Hatch Act of 1887 and the Morrill Act of 1890, established land-grant colleges in the United States. The combination of science with agriculture and animal husbandry was not uniquely American. See Williams, R.L.: 1991, The Origins of Federal Support for Higher Education, 12-13.

18 For instance, De Paul University in Chicago boasts of "one of the oldest" commerce schools in the country; and its commerce school dates from 1912. See DePaul University: 2004, De Paul: The Charles H. Kellstadt Graduate School of Business [accessed on 28 April 2004] (http://www.kellstadt.depaul.edu/html/about/index.shtml).

19 Allegedly, President Calvin Coolidge once said that "the business of America is business." See Bartleby, Inc.: 2002, The New Dictionary of Cultural Literacy, Third Edition. 2002 [accessed on 28 April 2004] (http:// www.bartleby.com/59/12/businessofam.html). However, some scholars object to this as "the most famous misquote of Calvin Coolidge." They cite a speech to the American Society of Newspaper Editors in Washington, D.C. on January 17, 1925 in which Mr. Coolidge said, "After all, the chief business of the American people is business." Cyndy Bittinger, The Business of America is Business? [accessed on 28 April 2004] (http:// www.calvin-coolidge.org/pages/history/research/ccmf/ bitt02.html).

20 A recent study showed that M.B.A. students displayed an ethical reasoning level on par and sometimes below that of convicted felons. See American Association of University Professors: 1999, 2/9/99 Daily Report from ACADEME TODAY [accessed on 9 February 1999] (http://chronicle.com). One recent study showed that business students had relative difficulty recognizing violence and were also relatively accepting of violence, based upon a situational questionnaire. Wines, W.A.: 2005, 'Does Capitalism Wear a White Hat or Ride a Pale Horse? Physical and Economic Violence in America and a Survey of Attitudes Toward Violence Held by U.S. Undergraduate Business Majors Compared to Ohio Valley Quakers,' Southern University Law Review, 33 (1), 103-211 at 153-162 (fall).

21 See, e.g., that only 8 of the Fortune 500 companies were headed by women as of January 2004. http:// weblogs.asp.net/rreese/archive/2004/01/05/47714.aspx [accessed on 29 April 2004] and citing http://www/azcentral.com/business/articles/0105womenceos05.html.

That number represented a substantial increase percentage-wise from 1997 when Fortune (June 9, 1997) listed two women CEOs of Fortune 500 firms and 7 CEOs 
of Fortune 1000 companies. http://www.mbnglobal.com/MBN_Money_Finance/women_ceos.html [accessed on 29 April 2004]. At that sustained rate of increase women would have control of one-half of the top corporations in America around the year 2250 A.D. For other anecdotal support for the assertion of whitemale dominance, see Regan, K.: 2004, Report: Global Internet is Male Dominated, [accessed on 29 February 2004] (http://www.ecommercetimes.com/perl/story/ 15875.html); and Lauer, N. C.: 2004, Studies Show Women's Role in Media Shrinking, [accessed on 29 February 2004] (http://www.womensenews.org/article.cfm/dyn/ aid/915). Excellence Guru and best-selling author Tom Peters agrees that corporate America is dominated by "old white males" and that "the lone woman occupies either the human resources or corporate communications job, while the lone African-American holds the other." McNair, J.: 2003, 'Speaker urges flexibility,' The Cincinnati Enquirer (November 22) D-1 at D-2.

22 For example at the Richard T. Farmer School of Business Administration, there were approximately 113 tenure-track faculty members in August 2003. Of these, approximately 17 (roughly 15\%) were women. See Miami University: 2003, Richard T. Farmer School of Business Administration Faculty/Staff Register - Oxford, (Fall 2003-2004) (August 14) (copy in possession of author).

23 For example, taking five business ethics books off the shelves in my office produced an unscientific but random sample of years and authors: (1) Baron, D.P.: 2000, Business and Its Environment, 3rd ed., (Prentice Hall, Englewood Cliffs, NJ) covers all three traditional pillars plus governmental theory, the news media, and an extensive treatment of international topics; (2) Bowie, N. and R. Duska: 1990, Business Ethics, 2nd ed. (Prentice Hall, Englewood Cliffs, NJ) covers all three traditional pillars; (3) DeGeorge, R. T.: 1995, Business Ethics, 4th ed. (Prentice Hall - originally MacMillan, Englewood Cliffs, NJ) covers all three traditional pillars and also applies moral reasoning to distinct functional areas of business, looks at famine and the changing social mandate of business; (4) DesJardines, J. and J. J. McCall: 1996, Contemporary Issues in Business Ethics, 3rd ed. (Wadsworth, Belmont, CA) covers all three traditional pillars and then looks at some current issues such as affirmative action, workplace safety, the environment, and multi-national corporations; and (5) Shaw, W. H.: 1999, Business Ethics, 3rd ed. (Wadsworth, Belmont, CA) has four main parts: (a) moral philosophy and business, (b) American business and its basis (examines corporations and capitalism), (c) organizations and the people in them (looks at workplace issues such as job security), and (d) business and society (looks at consumers and the environment). Essentially Professor Shaw covers all three traditional pillars plus some current issues in business ethics.

24 MacDonald, J. E.: 1989, 'Socratic Method and the teaching of law and virtue', Journal of Legal Studies Education, 7, 19-34 at 25. Here, elenchus is defined simply as "the refutation," the situation in which Socrates attempts to get the original speaker to admit a contradiction or, at least, that his original contention is inconsistent with his later declarations.

25 Lawrence Kohlberg used such "story problems" in ethics to generate the first empirical rating system for moral reasoning. (Kohlberg, 1984) Conry and Nelson, using Rest's standardized Defining Issues Test (DIT), later established that use of such hypothetical questions, which they termed "interventions," stimulated moral reasoning growth in undergraduate business law students. (Conry and Nelson, 1989).

26 See, e.g., Russell, B.: 1945, A History of Western Philosophy (Simon \& Schuster, New York), especially Chapter XX entitled "Aristotle's Ethics" in which Earl Russell declaims about Aristotle's Ethics, "More generally, there is an emotional poverty in the Ethics, which is not found in the earlier philosophers. ... For these reasons, in my judgement, his Ethics, in spite of its fame, is lacking in intrinsic importance." Id. at 184.

27 For a detailed description of this pedagogy and examples of the moral dilemmas, see Wines, W.A., H. L. Anderson, and M. P. Fronmueller: 1998, 'Accelerating Moral Development through Use of Experiential Ethical Dilemmas,' a unpublished paper presented at the Association for Business Simulation and Experiential Learning 25th Annual Meeting, Maui Intercontinental Resort, Maui, Hawaii, (January 4-6) (Copy in possession of the author).

28 See Sturdivant, F.D.: 1985, The Corporate Social Challenge: Cases and Commentaries, 3rd ed., (Irwin, Homewood, IL) 101-115. In 1970, Equity Funding Corporation of America began to "invent" insurance policyholders to keep from generating red ink and lowering its stock price. Equity then re-insured these bogus policies with Ranger National Life Insurance Company and other re-insurers. By 1972, virtually all the policies re-insured were phony, over $\$ 7$ million worth. Id. at 108-110. Presumably, over 100 people who worked at Equity Funding were knowledgeable about the scam; but not one came forward. Id. at 113. Two Peat, Marwick, Mitchell \& Co. auditors doing special examinations of Equity Funding for the Anderson, Clayton \& Co., a diversified Houston company with insurance interests, almost brought down the scandal in 1971, 16 months before it finally broke. However, the Peat, Marwick auditors who had become suspicious there might be phony policies were called off the job, and 
the firm never did issue even an informal report. Hill, G.C.: 1976, 'Accountants Brought Equity Funding Fraud Almost to Surface in "71: Long Before the Case Broke, Peat Marwick Was Hot on Firm's Trail, Until ..., Wall Street Journal (February 20) 1.

29 On the night before the Challenger disaster, two senior spacecraft engineers from Morton-Thiokol in Utah spent 6 hours pleading with N.A.S.A. to delay the launch of Challenger because of forecast overnight lows that would compromise the effectiveness of the O-rings made by their company. Just as they seemed to be on the verge of getting a delay, a company vice-president told them to go "off-line" for $5 \mathrm{~min}$ and said that they had to make a "management decision." It took $30 \mathrm{~min}$, not five. Ultimately, the two engineers were disenfranchised; and four senior managers voted to give N.A.S.A. the decision it wanted, approval to launch. See Staff: 2001, 'Special Report: Space Exploration: "I knew it was going to happen," The Guardian (January 23) [accessed on 18 July 2003] (http://www.guardian.co.uk/Print/0,3858,4121844,00.html). See also 'Engineering Ethics: The Space Shuttle Challenger Disaster', [accessed on 18 July 2003] (http://ethics.tamu.edu/ethics/shuttle/shuttle1.html); and Hoover, K. and W. T. Fowler, 'Studies in Ethics, Safety, and Liability for Engineers: Space Shuttle Challenge', [accessed on 18 July 2003] (http://www.tsgc.utexas.edu/ archive/general/ethics/shuttle.html).

30 Gascal, D.: 1981, 'Bemidji Classrooms will re-open today', Bemidji Pioneer (November 16) 1. "The contract settlement ended a 12-day-old strike, the first ever in Bemidji, ... The contract must still be approved by the Bemidji School Board, which should ratify the contract in the next two or three days, said Ted Thorson, school board chairman." Ted Thorson was a professor of music education at Bemidji State University; and Margaret Thorson, his wife, was an elementary school teacher who was active in the BEA (Bemidji Education Association). For a complete history of the news coverage of the strike, see generally The Bemidji Pioneer (January 9, 1981-December 15, 1981).

31 Lippmann, W.: 1940, The State of Education in this Troubled Age: A Sweeping Indictment of Modern Schools and Universities (unpublished address given at University of Pennsylvania, Philadelphia, PA on December 29, 1940 to the Annual Meeting of the American Association for the Advancement of Science) at 5, [accessed on 14 April 2004] (http://www.votd.com/lipp.html).

32 See Zink, N.: 1991, The Structure of Delight (Mind Matters Press, Santa Fe, NM) 60-63 wherein the author discusses open-mindedness and rigidity, which is characterized as people having a library in their heads with just one book. Zink notes that people with these "onebook" libraries guard them very cautiously against new information and experiences that might sneak into their one book with the gold title on the cover proclaiming "The Truth." Id. at 60.

33 Callahan, D. and S. Bok (eds): 1980, Ethics Teaching in Higher Education (Plenum Press, New York) 2 wherein the editors state, "[the moral philosophy course] aimed to pull together, to integrate and to give meaning and purpose to the students' entire college experience and course of study." In the 19th century, it was considered the "most important course in the college curriculum." Id.

\section{References}

AACSB, 'Standards For Business Accreditation,' (Adopted April 25, 2003 and revised January 01, 2004) as accessed at http://www.Aacsb.Edu/Accreditation/.

Academe Today, Daily Report at http://www.Dailychronicle.Com [accessed on 9 February 1999].

Adler, M. J.: 1987, We Hold These Truths: Understanding the Ideas and Ideals of the Constitution (MacMillan Publishing New York).

Alreck, P. L. and R. B. Settle: 1985, The Survey Research Handbook (Richard D. Irwin Homewood, IL).

The Associated Press: 2002, 'Enron Accused of Shredding Papers', Newsday.Com (Jan. 22, 2002), at http:// www.Newsday.Com/Newslocal/Longisland/Ny-BizEnron0122,0,5230445.Story?Coll=N.

Baron, D. P.: 2000, Business and its Environment (Prentice Hall Englewood Cliffs, NJ).

Barry, V. E.: 1979, Moral Issues in Business (Wadsworth Belmont, CA).

Berg, I.: 1989, 'Teaching 'Ethics in Business: Leave it to Sisyphus', in C. T. Mitchell (ed.), Values in Teaching and Professional Ethics (Mercer University Press, Macon, GA), pp. 111-132.

Berleson, B. and G. Steinier: 1964, Human Behavior, an Inventory of Scientific Findings (Harcourt, Brace \& World New York).

Blass, T. (ed.): 2000, Obedience to Authority: Current Perspectives on the Milgram Paradigm (Lawrence Erlbaum Associates, Inc., Mahwah, NJ).

Bloom, A.: 1987, The Closing of the American Mind (Simon and Schuster New York).

Bowie, N. and R. Duska: 1990, Business Ethics 2(Prentice Hall Englewood Cliffs, NJ).

Brady, F. N. and J. M. Logsdon: 1988, 'Zimbardo's 'Stanford Prison Experiment' and the Relevance of 
Social Psychology for Teaching Business Ethics', Journal of Business Ethics 7, 703-710.

Callahan, D. and S. Bok (eds.): 1980, Ethics Teaching in Higher Education (Plenum Press, New York).

Conry, E. J. and D. R. Nelson: 1989, 'Business Law and Moral Growth', American Business Law Journal 27(1), 139.

Cox, H.: 1999, 'The Market as God; Living in the New Dispensation,' The Atlantic Monthly (March), 8-23.

Crane, A. and D. Matten: 2004, Questioning the Domain of the Business Ethics Curriculum: Where the Law Ends or Where it Starts? (Research Paper Series ICCSR No $21-$ 2004, Nottingham) www.Nottingham.Ac.Uk/Business/ICCSR [Accessed on 9 July 2004].

Cronin, T. E.: 2004, 'The Art of Leadership: A LiberalArts Education Fosters Courage and Imagination - the Skills Needed to Tackle the Challenges of this Century', The Seattle Times (April 25), D1-D3.

DeGeorge, R. T.: 1995, Business Ethics, 4th ed. (Prentice Hall, Englewood Cliffs, NJ, originally Macmillan).

Desjardins, J. and J. J. McCall: 1996, Contemporary Issues in Business Ethics (Wadsworth Belmont, CA).

Dubrow, H. and J. Wilkinson: 1984, 'The Theory and Practice of Lectures', in M. M. Gullette (ed.), The Art and Craft of Teaching (Harvard University Press, Cambridge, MA).

Farrell, G.: 2006, 'Lay, Skilling Found Guilty: Both Men Could Spend Rest of Their Lives in Prison,' USA Today (May 26), 1B-3B.

Fraedrich, J. and O. C. Ferrell: 1992, 'Cognitive Consistency of Marketing Managers in Ethical Situations', Journal of Academic Marketing Science 20, 248-250.

Friedman, M.: 1970, 'The Social Responsibility of Business is to Increase its Profits', New York Times Magazine (September 13), 62-65.

Gascal, D.: 1981, 'Bemidji Classrooms will Re-Open Today,' Bemidji Pioneer (November 16), 1.

Gilligan, C.: 1982, In a Different Voice: Psychological Theory and Women's Development (Harvard University Press Cambridge, MA).

Gordon, R. A. and J. E. Howell: 1959, Higher Education for Business (Columbia University Press New York).

Greider, W.: 1997, One World, Ready or Not: The Manic Logic of Global Capitalism (Simon and Schuster New York).

Halbert, T. and E. Ingulli: 2000, Law \& Ethics in the Business Environment 3(West Legal Studies in Business Mason, $\mathrm{OH})$.

Haney, C., C. Banks and P. Zimbardo: 1973, 'Interpersonal Dynamics in a Simulated Prison', International Journal of Criminology and Penology 1, 69-97.
Hartman, L. P.: 1998, Perspectives in Business Ethics (McGraw-Hill Boston).

Hosmer, L. T.: 1987, The Ethics of Management (Richard D Irwin Homewood, IL).

Hosmer, L. T.: 1999, 'Somebody Out There doesn't Like Us: A Study of the Position and Respect of Business Ethics at Schools of Business Administration', Journal of Business Ethics 22(2), 91-106.

Jennings, M. M.: 1996, Case Studies in Business Ethics 2 (West Legal Studies in Business Mason, $\mathrm{OH}$ ).

Kaiser, S.: 2003, 'The Collapse of Enron: A Business Ethics Perspective', in N. Kubasek et al. (eds.), Contemporary Business Law in a Global Economy (Lakeshore Communications, Inc., Euclid, OH), pp. E1-E8.

Kelly, M.: 2002, 'It's a Heckuva Time to be Dropping Business Ethics Courses: MBA Programs are Downsizing Ethics Requirements at Precisely the Wrong Time', Business Ethics (Nov.-Dec.), www.BusinessEthics.Com [accessed on 25 March 2004].

Kohlberg, L.: 1984, Essays on Moral Development (Vol 2): The Psychology of Moral Development (Harper \& Row San Francisco).

Krauthammer, C.: 2004, 'So much for Democrats aiding poor', The Cincinnati Enquirer (April 9), B8.

Langewiesche, W.: 2003, 'Columbia's Last Flight: The Inside Story of the Investigation and the Catastrophe it Laid Bare', Atlantic Monthly (November), 58-87.

Lawrence, T. E.: 1926, The Seven Pillars of Wisdom: A Triumph (Doubleday, Garden City, NY, 1938, original privately printed in 1926).

Levin, M.: 1990, 'Can Ethics be Taught?', Reader's Digest (February), 113-114.

Lippmann, W.: 1940, 'The State of Education in this Troubled Age: A Sweeping Indictment of Modern Schools and Universities', (Unpublished Address Given at University of Pennsylvania, Philadelphia, PA On December 29, 1940 to the Annual Meeting of the American Association for the Advancement of Science), p. 5, accessed at http://www.Votd.Com/ Lipp.html on 4/14/2004.

MacDonald, J. E.: 1989, 'Socratic Method and the Teaching of Law and Virtue', Journal of Legal Studies Education 7, 9-34.

McHugh, F. P.: 1988, Keyguide to Information Sources in Business Ethics (Nichols Publishing New York).

Maslow, A. H: 1954, Motivation and Personality (Harper New York).

The Miami Bulletin: General Bulletin of Program Requirements and Course Descriptions 2002-2004: 2002 (Miami University, Oxford, OH).

Milgram, S.: 1963, 'Behavioral Study of Obedience', Journal of Abnormal and Social Psychology 67, 371-378. 
Milgram, S.: 1965, 'Some Conditions to Obedience and Disobedience to Authority', Human Relations 18, 57-75.

Miller, M. S. and A. E. Miller: 1976, 'It's too late for Ethics Courses in Business Schools', Business \& Society Review, 39-42.

Mitchell, T. R. and W. G. Scott: 1986, 'Markets and Morals in Management Education', Selections (Autumn) 3-8.

Mitchell, T. R. and W. G. Scott: 1990, 'America's Problems and Needed Reforms: Confronting the Ethic of Personal Advantage', Academy of Management Executive 4(3), 23-35.

Mulligan, T. M.: 1987, 'The Two Cultures in Business Education', Academy of Management Review 12(4), 593-599.

Noddings, N.: 1984, Caring: A Feminine Approach to Ethics and Moral Education (University of California Press Berkeley, CA).

Paine, L. S.: 1988, Ethics Education in American Business Schools (Ethics Resource Center Washington, DC).

Parks, S. D.: 1993, 'Is it Too Late? Young Adults and the Formation of Professional Ethics', in T. R. Piper et al. (eds.), Can Ethics be Taught, pp. 13-72.

Pierson, F. C., et al.: 1959, The Education of American Businessmen: A Study of University-College Programs in Business Administration (McGraw-Hill New York).

Piper, T. R., M. C. Gentile and S. D. Parks: 1993, Can Ethics be Taught? Perspective, Challenges, and Approaches at Harvard Business School (Harvard Business School Boston).

Premeaux, S. R.: 2004, 'The Current Link Between Management Behavior and Ethical Philosophy', Journal of Business Ethics 51, 269-278.

Prentice, R.: 2002, 'Lessons Learned in Business School', The New York Times (August 20), A19.

Rachels, J.: 2003, The Elements of Moral Philosophy 4 (McGraw-Hill New York).

Rawls, J.: 1971, A Theory of Justice (Harvard University Press Cambridge, MA).

Rest, J., et al.: 1986, Moral Development: Advances in Research and Theory (Praeger New York).

Roberto Rivera y Carlo: 2004, Business Ethics 101 (June 27, 2004), Boundless Webzine at http:// www.Boundless.Org/2002_2003/Features/ A0000672.html.

Rue, L. W. and L. L. Byars: 1986, Management Theory and Application 4(Irwin Homewood, IL).

Schaef, A. W.: 1981, Women's Reality: An Emerging Female System in the White Male Society (Winston Press Minneapolis, MN).

Shaw, W. S.: 1999, Business Ethics 3 (Wadsworth Belmont, CA).
Shaw, W. H. and V. Barry: 1998, Moral Issues in Business 7 (Wadsworth Belmont, CA).

Sloan, D.: 1980, 'The Teaching of Ethics in the American Undergraduate Curriculum, 1876-1976', in D. Callahan and S. Bok (eds.), Ethics Teaching in Higher Education (Plenum Press, New York), pp. 157.

Solomon, R. C. and K. R. Hanson: 1983, Above the Bottom Line: An Introduction to Business Ethic (Harcourt, Brace, Jovanovich, Inc New York).

Solomon, R. and K. Hanson: 1985, It's Good Business (Atheneum New York).

Stark, A.: 1993, 'What's the Matter with Business Ethics?', Harvard Business Review, 38-48.

Stone, C. D.: 1975, Where the Law Ends: The Social Control of Corporate Behavior (Harper \& Row Torchbook New York).

Sturdivant, F. D.: 1985, The Corporate Social Challenge: Cases and Commentaries 3 (Irwin Homewood, IL).

Sturdivant, F. D. and H. Vernon-Wortzel: 1990, Business and Society: A Managerial Approach 4(Irwin Homewood, IL).

Touche' Ross International: 1988, Ethics in American Business.

Trevino, L. K. and G. R. Weaver: 1994, 'Business ETHICS or BUSINESS Ethics: One Field or Two?', Business Ethics Quarterly 4(2), 113-128.

Vogel, D.: 1987, 'Could an Ethics Course Have Kept Ivan From Going Bad', Wall Street Journal (April 27), 22.

Waddock, S.: 2004, 'Hollow Men at the Helm', Biz Ed (July/August) 24-29.

Wartzman, R.: 1987, 'Nature or Nurture? Study Blames Ethical Lapses on Corporate Goals', Wall Street Journal (October 9), 27.

Weidenbaum, M.: 1990, Business, Government \& Society 4 (Prentice Hall Englewood Cliffs, NJ).

Williams, R. L.: 1991, The Origins of Federal Support for Higher Education (Pennsylvania State University Press University Park).

Wines, W. A.: 1999, Readings in Business Ethics and Social Responsibility (Kendall/Hunt, Dubuque, IA).

Wines, W. A.: 2004, 'Anatomy of the AFSCME Strike at Miami University: Should Higher Education Engage in Corporate-Style Strikebreaking?', Labor Law Journal 55(1), 17-20.

Wines, W. A: 2005, 'Does Capitalism Wear a White Hat or Ride a Pale Horse? Physical and Economic Violence in America and a Survey of Attitudes Toward Violence Held by U.S. Undergraduate Business Majors Compared to Ohio Valley Quakers', Southern University Law Review 33(1), 103-211. 
Wines, W. A.: 2006, Ethics, Law, and Business (Lawrence Erlbaum Associates, Inc Mahwah, NJ).

Wines, W. A. and N. K. Napier: 1992, 'Toward an Understanding of Cross-Cultural Ethics: A Tentative Model', Journal of Business Ethics 11, 831-841.

Wines, W. A. and J. B. Hamilton, III: 2004, 'Observations on the Need to Redesign Organizations and to Refocus Corporation Law to Promote Ethical Behavior and Discourage Illegal Conduct', Delaware Journal of Corporate Law 29(1), 43-82.

Zimbardo, P., C. Maslach and C. Haney: 2000, 'Reflections on the Stanford Prison Experiment: Genesis, Transformations, Consequences', in T. Blass (ed.), Obedience to Authority: Current Perspectives on the
Milgram Paradigm (Lawrence Erlbaum Associates, Inc., Mahwah, NJ) pp. 193-237.

Zimbardo, G.: 1972, 'Pathology of Imprisonment', Society 9(6), 4-8.

Zink, N.: 1991, The Structure of Delight (Mind Matters Santa Fe, NM).

Business Department, PH 305, Missouri Western State University, School of Professional Studies, St. Joseph, MO, 64507, U.S.A. E-mail:wwines@missouriwestern.edu 